\title{
SCIENCE AND NATIONAL WELFARE*
}

\author{
By Sir William BragG, O.M., K.B.E., F.R.S.
}

$\mathrm{M}^{2}$ ANY events conspire to make the past year notable in the history of the Royal Society. Reference has been made to the majority of them in the Annual Report of Council, usefully supplemented by the Notes and Records which we continue to owe to our past Treasurer, Sir Henry Lyons. I do not propose to speak of them in detail, but on this occasion it does seem fitting to give further attention to one or two general matters of lasting interest.

One of these is personal. Fellows will have noted the long list of those whom we have lost, and the great names which the list contains. I have felt as $I$ have been reading it that $I$ have turned over the last leaves of a chapter that stands by itself. The present generation is quick to honour the names of J. J. Thomson and Oliver Lodge; but they cannot remember, as we older men can, the brilliant years when these men and their contemporaries were writing the chapter's first pages: What they wrote was eagerly read, their lectures were heard with rapt attention; they were the pioneers, and the men of science of that time, nearly half a century ago, streamed after them. All that is now a memory. The years have slipped away since their work was done, and we now look back on it as a separate entity, a noble event in the history of science, and of British science in particular.

There is no vestige of sadness in such a retrospect, nor any trace of feeling that our pride must be founded only on what has passed. I am sure that all those who like myself can recall the long years, and compare those that have gone by with those that are still ours, will say happily and proudly that our young men of to-day are maintaining in full force the tradition that they have received. They are writing a new chapter ; and it is a chapter of a novel importance, because as they extend our record of the facts of Nature they find themselves compelled at the same time to consider a new problem - the relation of those facts to society and to the government of nations. Let me express my admiration of the willingness, vigour and ability with which the newer generation gets to work.

This same novelty is enlarging the range of

* From the presidential address to the Royal Society, delivered on November 30. work of our Society and is a second matter to which we are compelled to give serious attention. Our fellows have constantly given their services to public interests ; it has often been pointed out that they are to be found in association with almost every department of government. But this year new moves have been made which may, and I hope will, lead to developments of the highest importance. The Report contains a notice of the recent formation of a Scientific Advisory Committee over which Lord Hankey presides, with a reference which in effect directs it to consider the advances of science in their relation to national welfare. The Committee reports to the Cabinet through its chairman. A Committee of similar nature but lesser scope was set up a few months ago to consider the scientific aspects of the food policy of the Government: it consists of well. known authorities on nutrition, agriculture and economy, with myself as chairman. This Committee reports to the Lord Privy Seal, and so to the Cabinet Food Policy Committee over which the Lord Privy Seal presides. The significant feature of these Committees is their close and direct association with the Cabinet, the central body that governs the nation.

Hitherto men of science have been appointed man by man to various Government departments so that they might act as useful items in departmental machinery. The new Committees are not parts of any executive body and have no executive power of their own. They exist to make recommendations, which must of course be practical and take full account of difficulties of execution. But they are not hampered by traditions, nor by set habits; they have time and freedom to consider the whole field of scientific knowledge and its possible influence on practice. The Scientific Advisory Committee, the more important of the two, is particularly well fitted to watch all occasions and opportunities for the employment of science in the service of the nation, and also for the continuous encouragement of that employment. The president of the Society and the two principal secretaries are in close touch with every branch of science; through the fellows of the Society which they serve they have a unique view of scientific progress. The three secretaries of the 
principal Research Councils of the Government, dealing with industry, agriculture and health, are in close touch with the chief national activities.

Thus a great opportunity is opened after long expectation; and the Royal Society is largely responsible for the development of that opportunity. We hope that no hindrances from without may interfere with the Society's task, and we are determined that there shall be no lack of energy from within.

We remember that it is science itself, not men of science, that we are trying to lift to the high places. In that respect our movement is not selfish. We do not claim that men of science shall be entrusted with authority because they are men of science: we do claim that authority shall be exercised in the light of a knowledge which grows continuously, and with continual effect on politics, on industry, and on thought itself. If at present the only way to bring this knowledge into use is to treat men of science as consultants, let us take that way. But we shall be taking the better way if in all ranks of the State, and especially in those that have authority and set an example, we can arouse a general appreciation of the position of, and a constant understanding watchfulness on, the increase of knowledge and the uses that are made and can be made of it. It cannot be said that the general aspect of the nation towards the increase of knowledge is satisfactory. Science has become an integral part of our educational system, yet the changes that have been made are often ridiculously like the casting of sacrifices to following wolves. Science is not a devouring monster, but a means of service; it is a knowledge, gained by an irresistible tendency of man to examine his surroundings. It may be rightly or wrongly used. There is a prime danger if those who are in the position to use it rightly shut their eyes to its presence and its power, like an army which relies on bows and arrows when its enemies know how to use machine guns.

It is not universally or even sufficiently understood how important natural knowledge has become. It is true that in a vague way the nation is brought by the happenings of war to guess at the meaning of scientific research in every kind of enterprise. But still it would be difficult for most people to grasp the significance, much less the meaning, of the description of a fact like this : that the Royal Air Force could not carry out its operations without the knowledge resulting from the studies of cathode rays and electrons made by our physicists, which is equivalent to saying that by this time we might well have lost the War. Similar cases of cause and consequence could be quoted in numbers; they happen to be found more readily in relation to the sciences that deal with inorganic materials than those that deal with organic processes, and the military demand for physicists has been great because they are wanted to put physical discoveries into practice. But this discrimination is only accidental and temporary, and in fact the whole range of science is equally concerned.

Since experimental science has assumed such a commanding influence on all our affairs, so that we run the risk of great perils if we take no account of it, and leave its uses to others, let us say, less well disposed than ourselves, and, on the other hand, have opportunities of great benefit if we use it rightly, it becomes a first duty to direct our steps accordingly. Just as in former times schools and colleges were founded to train men for the service of Church and State, in ways which were appropriate to that high end, so now we have to see to it that the men are produced by our educational systems who can appreciate and act up to a new state of affairs. This can be done without jettisoning any of the fine instruction which has been a proud feature of our older systems.

I think that this is not essentially a matter of the rearrangement of school time-tables, or the building of scientific laboratories, though such tactical methods must have their due consideration. This is a personal matter, as has been the case with every great human movement. We have not to force the use of new tools, but to encourage and develop a new appreciation and a new attitude. Our best method, as ever before, lies in our own actions. If we, in the continually increasing contacts of men of science with public affairs, can show that we have something of great value to contribute, and that we give it freely, placing our individual interests below those of a greater purpose; if we try to understand the motives and principles of those whom we meet who may not see our vision, just as we may fail to appreciate theirs, then by so doing we have the best chance of bringing about the changes that we desire. It is the personal contact of the man of science, especially with those who are charged with duties to the nation, that is the moving force. That is where these new associations of science with government may mean so much, and shall mean it, if our devotion can achieve its purpose. 